\title{
China's Environmental Vertical Management Reform: An Effective and Sustainable Way Forward or Trouble in Itself?
}

\section{Di Zhou}

School of Marxism, Wuhan University, Wuhan 430072, China; dzhou_law@whu.edu.cn

Received: 23 September 2020; Accepted: 2 November 2020; Published: 11 November 2020

\begin{abstract}
An environmental management system provides the institutional foundation for sound environmental governance. Conventional environmental management systems, deriving from the combination of the vertical management of competent authorities and the localized management of local governments, can lead to local protectionism and implementation deviation at the local level. Since 2016, environmental vertical management reform has been performed as a significant part of the overall promotion of the ecological civilization in China. Representing the most fundamental reform of China's local environmental management system since the Environmental Protection Law of 1989, the environmental vertical management reform focuses on the reconstruction and adjustment of the environmental management functions among the local governments, and their environment protection authorities at the provincial, city, and county levels. In this paper, we provide an overview of the basic theory of the vertical management model, as well as the motivation for-and the legal/policy background, focuses/content, local practices, and results of -the environmental vertical management reform in China. In the discussion section, we analyze the current problems that impede the effectiveness and sustainability of this reform. On the basis of the analysis of the present and the problems, we raise the question of whether this round of reform is effective and will be sustainable in the future. In response to the challenges, feasible recommendations are proposed. These suggestions include firmly promoting the rule of law in the process of implementing the reform, enhancing the institutional supply and capacity building at the grassroots level, and taking advantage of the holistic governance under the leadership of the Communist Party of China (CPC).
\end{abstract}

Keywords: China; vertical management reform; environmental management; policy

\section{Introduction}

Although China's environmental legal system has given rise to many plans, many policies, and much legislation, it has been plagued by 'weak law enforcement', referring to the poor results from the enforcement of environmental laws, and 'difficult law enforcement', meaning systematic impediments to the monitoring and management work of law enforcement entities. The ineffective environmental management system has created a bottleneck in the government's environmental protection work, and is a systemic cause of environmental pollution and ecological destruction (Ran 2015). Here, the environmental management system refers to the environment protection authorities across all of the levels established by the state, their assigned powers, and their assumed responsibilities. The environmental management system is the basis and main content of environmental governance, and it provides the institutional foundation for environmental improvement. In order to address the conspicuous problems affecting China's environmental management system during this challenging time, with China 'plunging into the deep end' in its commitment to strive toward an ecological civilization, systemic reform has become the central task. 
China's environmental management system began taking shape in the 1970s, and was enshrined in the Environmental Protection Law in 1989. The conventional environmental management system is characterized as being supervised by the National People's Congress, managed on a unitary basis by the competent central authority in charge of environmental protection, and implemented by governments and their relevant departments across all levels (Cai et al. 2015). More specifically, according to the Environmental Protection Law (Environmental Protection Law of People's Republic of China 2014), the local governments at various levels bear responsibility for the environmental quality of their administrative areas; environment protection authorities at various government levels perform the unitary management of the environmental protection work. Considering the interdisciplinary nature of environmental governance, relevant competent authorities (forest, water, agriculture, transport, energy, etc.) should also be included in the environmental management system by managing the specific environment issues under their jurisdictions and actively coordinating with the Environment Protection Authority.

For a long period, since the 1980s, the environmental management system followed the traditional model of administrative management in China, which combines vertical management led by a superior competent authority in the specific field (described as 'line management') with overall horizontal and localized management led by the government across the different levels (described as 'block management') (Ma 1998). This structure, combining 'line management' and 'block management' (Figure 1), constitutes the foundation of the inter-governmental relationships in China's state governance, and has deeply shaped the process of advancing the modernization of China's system and capacity for governance (Zhou 2020).

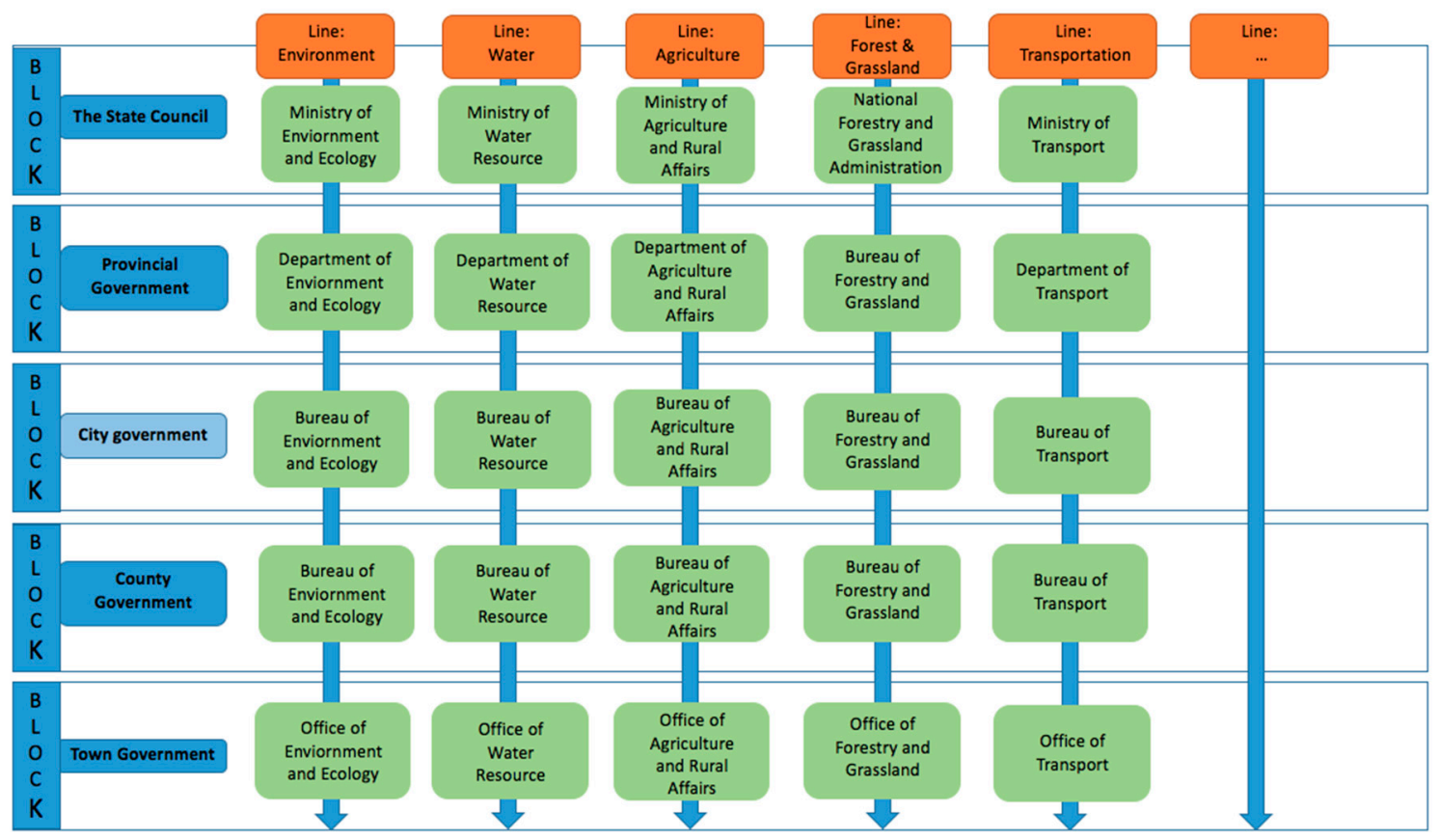

Figure 1. Conventional 'line-block' management structure.

Under the combined 'line-block' management structure illustrated in Figure 1, 'line management' represents top-down control by a competent authority in a specific field, while 'block management' represents localized management by the local governments. As a consequence, the balance of the subtle game between the 'line management' and the 'block management' changes with the turning trends of centralization or decentralization. We take the environmental management system as an example. Under the conventional structure, a local environment protection authority is identified both as an inferior authority of its superior environment protection counterparts and as an indispensable part of its local government. 
This dual identity has resulted in complexities in identifying the power and responsibilities among the governments and their relevant departments. In addition, due to the personnel and financial constraints on their environment protection departments, local governments have vastly more actual impact on local environmental protection management issues than do the central or superior environmental protection competent authorities. Considering the 'block' power overweighing the 'line' power, researchers proposed that, sometimes, such a management system can lead to local protectionism, deviations in local policy implementation (Chen et al. 2013), and a local race to the bottom.

Reforming the environmental management system is, thus, imperative, and this reform must involve both horizontal and vertical aspects. Horizontal reform should chiefly address the dispersion of environmental protection management functions throughout the relevant authorities, and should address the lack of effective coordination. The 'super-ministry system' reforms, which aim to integrate the fragmented functions relating to the environment protection of various relevant authorities into the Ministry of Ecology and Environment, mainly target these problems (Zhao 2018; Institutional Reform Plan of the State Council 2018). The vertical management model investigated in this paper chiefly focuses on vertical reform.

In September 2016, the joint issuance of the Guidelines for the Pilot Program for the Vertical Management Reform of Environmental Monitoring, Inspection and Law Enforcement below the Provincial Level (below, Guidelines) by the General Office of the Central Committee and the General Office of the State Council formally initiated the environmental vertical management reform (Guidelines for the Pilot Program for the Vertical Management Reform of Environmental Monitoring, Inspection and Law Enforcement below the Provincial Level 2016). This represented the most fundamental reform of China's local environmental management system since the establishment of the Environmental Protection Law in 1989 (Ding 2016). This round of reform consists of a complex bundle of measures that are intended to separate the internal functions of the environment protection agencies into three categories, at all levels. The goal is to resolve the most salient problems affecting the local environmental management system (Zhou 2016b). In reality, in responding to ongoing calls to implement vertical management reform in the domain of environmental protection, some local governments had already attempted to enact environmental vertical management reforms into practice ( $\mathrm{Li}$ and Shen 2011). However, it was not until the issuance of the Guidelines that the environmental vertical management reform was implemented on a national scale.

The current round of reform has been welcomed with the major expectation that it will achieve substantial progress, providing an effective and sustainable way forward in realizing 'good governance' in environment protection in China. Since the implementation at trial points in 2016, it has proven effective in areas such as the strengthening of law enforcement at the grassroots level, improving the working efficiency and effect of environmental management, the handling of interregional environmental protection problems, and the realization of local governments' environmental protection responsibilities. However, at the same time, the challenges that have emerged in practice have, to some degree, canceled out the achievements of the reforms, turning the reform into a trouble itself, instead of a way forward.

The existing literature has provided comprehensive theoretical research on the rationale (Ding 2016; Sun 2016a) and the problems of environment vertical management in legal and policy perspectives right after the implementation of reform at national level, but in a theoretical way (Ma 2017). Now that four years have passed since 2016, the examination and evaluation should be performed on the local practices in order to analyze the problems in reality, and to rethink the theoretical basis of vertical management and propose more targeted suggestions. In this commissioned paper, we took environmental vertical management reform as our research subject, and investigated the focuses, content, effects, problems, and future developments of reform in order to answer the following questions:

(1) What was the background context at the time that the environmental vertical management reform was implemented? 
(2) What were the proposals under the reform?

(3) What have been the results of reform?

(4) Have problems been encountered during the implementation process? How should the problems currently being encountered in practice be resolved?

(5) Is the environmental vertical management reform an effective and sustainable way forward? In what direction should the reform of China's environmental management system proceed in the future?

On the basis of the analysis on these questions and in response to the current challenges of the reform, feasible recommendations are proposed. These recommendations, in the framework of the better balancing of the conflicts between the innovative aspects of reform and the stability of the rule of law, aim to guarantee an effective and sustainable environmental management reform in the long run.

\section{Methods}

The line of research developed, as well as the research questions to be addressed in this paper, call for doctrinal research together with socio-legal research methods, i.e., the case studies of local practices and open-ended interviews.

The legal/policy documents are selected national laws and the policies for the reform, mainly including the 'Environmental Protection Law of the People's Republic of China' (2014 version), the 'Organic Law of Local People's Congresses and Local People's Governments at All Levels' (2015 version), the 'Guidelines for the Pilot Program for the Vertical Management Reform of Environmental Monitoring, Inspection and Law Enforcement below the Provincial Level' (2016), 'Decision of the CPC Central Committee on Some Major Issues Concerning Comprehensively Deepening the Reform' (2013), 'Recommendations of the CPC Central Committee for the 13th Five-Year Plan for Economic and Social Development' (2015), and 'Opinions of the CPC Central Committee and the State Council on Accelerating Ecological Civilization Construction' (2015). There is limited legal literature on the examination and reflection on the effectiveness and sustainability of the environmental vertical management reform in China. This research will also provide an in-depth literature review on the research papers and opinions in particular.

Furthermore, multiple case studies were used to analyse the status quo and the challenges of local practices in implementing the environmental vertical management reform. The documents explaining the local practices were collected on the local governments' websites and selective news websites.

The open-ended interviews were conducted with five government officials from the environment protection authority of Hubei Province in November 2019, in order to look into the implementation of environmental supervision under the reform in Hubei. Five detached inter-regional environmental supervision institutions have been set up since 2016, covering the whole area of Hubei Province. The five officials are from one of these five detached inter-regional environmental supervision institutions, namely the central Hubei inter-regional environmental supervision institution. Its jurisdiction covers the cities of Jingzhou, Jingmen, Xiantao, Qianjiang and Tianmen, with a total population of over 13 million. There are, overall, 22 officials of the inter-regional detached institution. The topics discussed during the interviews with the five officials include, but are not limited to:

- What are their duties and responsibilities as officials of the detached inter-regional institutions?

- Who and which department do they mainly target?

- What are the procedures of supervising?

- How do they evaluate the effectiveness of their supervision work? Etc.

The open-ended interviews were carried out in the forms of two group meetings (one with two officials and one with three officials) of $3 \mathrm{~h}$ in total. The interviews were recorded with a transcript of selected content available. 


\section{Results: Theory Basis, Policies, Practices, and Achievements Concerning the Environmental Vertical Management Reform}

\subsection{Theoretical Analysis of the Vertical Management Model}

What is vertical management? The traditional localized management system involves the dual leadership of the local government and the superior authority, with the superior authority bearing responsibility for operational leadership, and the local government bearing responsibility for the leadership of the people, funds, and materials (Li 2020a). In comparison, vertical management implies the basic separation of environmental management authority from local government control (Zhou 2019), freeing environmental management from the constraints of local governments' supervisory mechanisms, putting provincial or central agencies directly in charge of people, funds, materials, and matters. Vertical management can be further classified into central vertical management, provincial vertical management (Ren 2016), and special vertical management, which chiefly refers the inter-provincial management institutions established under central government agencies (Wang 2013b).

Under a traditional environmental management system, although the local environment protection authority is subject to dual leadership by the superior environment protection authority and the local government (Ren 2016), the latter's people, funds, and materials obviously will have greater influence than the former's operational authority. This model is directly connected with China's division into administrative regions, and with the bureaucratic structure of the administrative organizational system. When the interests of the central and local governments are aligned and, particularly, when the local government is strongly motivated to protect the environment, this model can ensure the integrity of local government while also strengthening the professionalism of management in specific fields (Liao and Lin 2016). In this case, it can be considered to be a model with a clear hierarchy and efficient operations. However, the interests of the central government and local governments are not always closely aligned in practice. For instance, in a tournament system (Zhou 2009; Li and Zhou 2005), motivated by the prospect of promotion chiefly determined by indicators of economic benefit, local officials typically vigorously pursue achievements with significant short-term economic benefits (such as GDP growth) while paying little attention to long-term tasks with cumulative effects (such as environmental protection) (Chen 2008; Zhang and Qi 2010). Despite the Central Committee's promotion of the ecological civilization to a national strategy at the 18th National Congress of the CPC, this 'tournament' phenomenon has persisted (Yuan and Jiang 2020). Although the index of environmental protection has been added into the overall evaluation and assessment system of the superior government, some officials of inferior governments still don't take it seriously, for the reason that it will take a relatively long time for the results of the efforts in environmental protection to occur, thus leaving the impact of the index of environmental protection on the overall performance almost negligible (Eaton and Kostka 2014). Besides this, the quantization index sometimes leads to falsified statistics or selective implementation by intentionally focusing on the measurable issues and neglecting the harder-to-measure issues (Ran 2013). Vertical management seeks to wean local governments from their habitual choices and path dependence by reconfiguring the power relationship between local governments and their environment departments so as to weaken the local governments' control over local environmental authorities, which will also serve to restrict the local officials' power to intervene in and interfere with environmental affairs. This is the original aspiration in designing the vertical management reform.

Vertical management models are certainly not unique to the field of environmental protection, and models similar to vertical management also exist in fields such as industry, business, quality supervision, property tax, land management, and food and drug management. For example, in business and industry, local governments' bureaus of commerce and industry are subject to the direction and supervision of superior agencies, and their leadership is subject to dual management, which consists chiefly of local management. In taxation, local tax agencies below the provincial level are subject to the dual leadership of the superior tax agencies and the government at the agency level, which consists 
chiefly of vertical leadership by the superior tax agency; here, the people, funds, and materials involved in tax affairs at the city and county levels are subject to vertical management by the local tax bureaus at the provincial, autonomous region, or municipality level. In the field of land management, township land management offices are subject to the management of their organizational structure by the county people's government, and the county may establish a township (town) or district land management office in light of the actual circumstances and working needs; this office serves as a detached office for the county's land resources' competent authority. The vertical management models in these fields have enabled an accumulation of much practical experience that can be applied to environmental vertical management reform. It can be seen from existing vertical management practices that vertical management models have very significant advantages over the conventional model. By providing effective safeguards for people, funds, and materials, a vertical management model can ensure that the vertical management authority is not affected by local protectionism while facilitating the full implementation of decrees and ensuring the consolidation of central authority. The advantages of a vertical management model chiefly consist of the following three aspects. First, this model can enhance the working efficiency of the competent authorities of local governments. Under a vertical management model, local competent authorities' personnel affairs, funding, and operations are relatively independent, and are subject to strong safeguards, are relatively immune to interference from other factors, and can ensure high levels of standardization and professionalism in administrative law enforcement. Second, this model can promote scientific decision-making. Since the vertical management models can reduce the number of levels through which information must be transmitted, the authorities can better ensure the veracity and validity of grassroots-level information, which can serve as a reliable basis for development decisions. Third, this model can consolidate central-local checks and balances. The vertical management system can prevent local government authorities from 'transgressing' or 'overstepping', and ensure that both horizontal and vertical powers remain in a state of equilibrium in the midst of dynamic adjustments.

However, from another perspective, vertical management models are also subject to certain abuses. The first is the lack of self-supervision mechanisms. The competent authority is geographically distant, and if there is a lack of effective guarantees of people, funds, and materials, the flow of information may be uncertain, and the supervisory costs could be high. Because the local party committee and government cannot perform substantive supervision on their competent authorities, ensuring that the authority exercises its powers in accordance with the law is a key problem (Guo 2008). Second, there is a lack of an effective incentive mechanism. Under the vertical management model, local competent authorities and local governments have different policies governing personnel appointments and removals, cadre promotions, wages, and benefits, among others. In reality, the local competent authorities' personnel will have relatively little chance of assuming a position at their superior units, much less have the opportunity to obtain a position with the local government. As a result, these personnel will face a career ceiling. Additionally, as the central and local governments have separate budgets, there may be a large salary difference between a local competent authority's personnel and the local government personnel. Third, the effectiveness of checks and balances may be lower than expected. Due to the lack of supervision and incentive mechanisms, a local competent authority may be unable to fulfill the expectations of the reform when implementing administrative orders from the superior authority.

In view of vertical management models' theoretical diversity, and their mixed advantages and disadvantages, the way in which to effectively promote vertical management reform in the area of environmental protection—so as to maximize this model's strengths and minimize its weaknesses-is a great challenge. 


\subsection{Motivation for the Reform}

\subsubsection{Ineffectiveness of the Conventional Environmental Management System}

The first motivation for the reform is the deviations in implementation. Conventional environmental management systems permit local governments to exercise their environmental administrative powers in accordance with local conditions and the state of environmental resources within their administrative districts, and the central government cannot effectively curb local governments' exercising of their environmental administrative powers. When supervising local governments' implementation effectiveness, the central government faces the dual constraints of information asymmetry and limited capabilities, while local governments are motivated to engage in the partial or distorted implementation of national environmental policies (Zhou and Liu 2008). The localized environmental management system allows some localities to emphasize development while neglecting environmental protection, to interfere with environmental monitoring and enforcement, and to make environmental responsibilities difficult to fulfill. As a result, laws are not complied with and numerous violations are not pursued. The salient problem of "difficulty in eliminating the interference of local protectionism with environmental supervision and enforcement" persists (Xi 2015).

The second motivation is the hampered effectiveness. Under a conventional environmental management system, when the environmental protection authority actively manages the area under its jurisdiction, 'rational' local governments will have no motivation to engage in management if the authority wishes to address interregional environmental problems which will have spillover effects for adjacent administrative regions; under such circumstances, effective governance is unlikely to occur (Sun 2016a). The broad conflicts between an environmental management system based on administrative regions and the integrated ecological system will tend to hinder the establishment of effective environmental governance.

The third motivation is inadequate capabilities, particularly at the grassroots level. Under a conventional environmental management system, the strength of the enforcement power takes the form of an inverted pyramid, with the monitoring and enforcement capabilities at the grassroots level being unable to meet the needs of front-line environmental management. Taking Shanghai as an example, there are fewer current employees in the municipal and regional environmental protection systems than the authorized permanent staff, and the environmental management and law enforcement teams typically have insufficient specialists, with a lack of senior talent. In particular, personnel in rural areas commonly perform environmental protection work on a part-time basis, and one person may have to manage several areas. As a result, the strength of environmental protection assistance is much lower than is needed (Wang 2016).

The fourth motivation is the alienation of responsibility. Although the Environmental Protection Law specifies that local people's governments are responsible for the environmental quality within their areas of jurisdiction, the current law does not clearly specify the ways in which local governments can be held accountable. When environmental pollution events or other environmental problems occur, the local environment protection authority, which is both part of the local government and the competent authority in charge of environmental protection work within its area of jurisdiction, will of course be the ultimate responsible entity (Yan 2015). However, most of the time, due to overt or implicit restraint by local governments and other superior competent authorities, the environment protection authority does not take action against environmental pollution events and other environmental problems. Taking the review of infrastructure construction projects' environmental impact assessments as an example, due to the weak position of environment protection authorities, environmental impact assessments are typically reviewed by some other competent authorities, who treat them as a minor issue. As a result, environmental impact assessment reviews tend to have little regulatory force. However, as soon as a project causes environmental problems, the environment protection authority is subject to criticism, and will be employed as a shield ( Xu 2020). The alienation of responsibility occurs 
because the environment protection authority is unable to independently enforce the law due to its lack of a voice, but it must still serve as the ultimate responsible entity.

\subsubsection{Forceful Promotion of Systemic Reform after the 18th National Congress of the CPC}

In promoting the ecological civilization to the level of a national strategy at the 18th National Congress of the CPC, China's political and government leaders also proposed a 'Five-Sphere Integrated Plan' and the 'Four Comprehensives' strategic blueprint for the establishment of an ecological civilization. The content of this plan and blueprint calls for the accelerated development of an effective institutional system for an ecological civilization, and for the establishment of an environmental management system characterized by integrated management, a hierarchical structure transcending conventional administrative districts, and the rational allocation of powers and responsibilities across all the government levels. Numerous documents concerning these reform goals have been issued subsequently (Table 1 ).

Table 1. Normative documents concerning environmental vertical management reform since the 18th National Congress of the CPC.

\begin{tabular}{|c|c|c|}
\hline Time & Document & Reform Requirements \\
\hline 2013 & $\begin{array}{l}\text { Decision of the CPC Central } \\
\text { Committee on Some Major Issues } \\
\text { Concerning Comprehensively } \\
\text { Deepening the Reform }\end{array}$ & $\begin{array}{l}\text { Establishment and comprehensive, strict supervision of } \\
\text { all environmental management systems concerning } \\
\text { pollutant emissions, independent implementation of } \\
\text { environmental supervision and } \\
\text { administrative enforcement }\end{array}$ \\
\hline 2014 & $\begin{array}{l}\text { Decision of the CPC Central } \\
\text { Committee on Major Issues } \\
\text { Pertaining to Comprehensively } \\
\text { Promoting the Rule of Law }\end{array}$ & $\begin{array}{l}\text { Use of a strict legal system to protect the } \\
\text { ecological environment }\end{array}$ \\
\hline 2015 & $\begin{array}{l}\text { Opinions of the CPC Central } \\
\text { Committee and the State Council } \\
\text { on Accelerating Ecological } \\
\text { Civilization Construction }\end{array}$ & $\begin{array}{l}\text { Strengthened supervision and law enforcement } \\
\text { targeting waste of energy and resources, illegal pollutant } \\
\text { emissions, destruction of the ecological environment } \\
\text { and investigations of specific cases; resource and } \\
\text { environmental supervisory agencies enabled to } \\
\text { independently conduct administrative law enforcement }\end{array}$ \\
\hline 2015 & $\begin{array}{l}\text { Recommendations of the CPC } \\
\text { Central Committee for the 13th } \\
\text { Five-Year Plan for Economic and } \\
\text { Social Development }\end{array}$ & $\begin{array}{l}\text { Realization of a vertical management system } \\
\text { encompassing monitoring, supervision, and law } \\
\text { enforcement by environment protection agencies below } \\
\text { the provincial level; exploration of the potential to } \\
\text { establish interregional environment protection agencies; } \\
\text { initiation of roving environmental supervisory } \\
\text { inspections, and strict enforcement of environmental } \\
\text { protection laws }\end{array}$ \\
\hline 2016 & $\begin{array}{l}\text { Guidelines for the Pilot Program } \\
\text { for the Vertical Management } \\
\text { Reform of Environmental } \\
\text { Monitoring, Inspection and Law } \\
\text { Enforcement below the } \\
\text { Provincial Level }\end{array}$ & $\begin{array}{l}\text { Establishment of an authoritative, highly effective local } \\
\text { environmental management system effectively } \\
\text { integrating departments and regions at all levels, } \\
\text { in which each unit performs its own functions and has } \\
\text { clearly defined duties and powers and adequate logistic } \\
\text { support; this system shall be responsible for the strict } \\
\text { supervision of local governments and their relevant } \\
\text { departments and shall enhance the independence, unity, } \\
\text { authoritativeness, and effectiveness of environmental } \\
\text { supervision and law enforcement }\end{array}$ \\
\hline
\end{tabular}


It can be seen from the progress in environmental vertical management reform that, as the environmental protection super-ministry system reform gradually proceeds, the problems related to multiple regulators, cross supervision, and fragmented management are being resolved to some extent, and the horizontal relationships within the environmental supervision system are gradually being clarified. The success of environmental protection super-ministry system reform has increased the confidence in promoting environmental vertical management reform. It is time to accelerate the pace of vertical reform, as the vertical relationships within the environmental management system are key factors limiting its effectiveness.

China has conducted a large number of practical experiments connected with vertical management reform. Starting in 1998, China successively embarked on vertical management reform in market regulation (Chen 1999), quality supervision (Zheng et al. 2013), property taxes (Mao 2019), land management (Li et al. 2012), and food and drug supervision (Wang 2013c). As a result, China has accumulated extensive experience concerning reform measures, methods, and steps, providing a reference model for the promotion of environmental vertical management reform.

\subsection{Highlights of the Reform}

According to the Guidelines, the focus of the environmental vertical management reform is the reconstruction and adjustment of the environmental management functions among the local governments and their environment protection authorities at the provincial, city, and county levels. The environmental vertical management reform has been conducted on the basis of the internal division of the functions and the organizational adjustment of the environment protection authorities at the city and county levels.

The first highlight of the reform is the 'M-S-E framework' of function division. Here, the 'M-S-E framework' refers to the division of the overall environmental management functions into three categories, namely Monitoring, Supervision, and Enforcement. Under this framework, the function of 'Monitoring' means detecting the environmental pollutants and the environmental quality by using chemical, physical, biological and other methods, in order to provide a scientific reference for decision making (Han 2018); the function of 'Supervision' is the supervision of the governments and their departments at all levels on their performances in environmental protection; and the function of 'Enforcement' is the administrative enforcement of the law (e.g., on-site inspection and administrative penalties) in accordance with the Environmental Protection Law and relevant regulations. The aim of this division is to realize a rational allocation of competences between environment protection authorities at various levels, thus changing the phenomenon of 'isomorphic competence', in which the environment protection authorities at all levels take exactly the same functions.

Before discussing the allocation of competences, the second highlight of the organizational adjustment of environment protection authorities needs to be analysed. There are two changes specified in the Guidelines.

The first is that, although the city-level environment protection authorities are subject to dual management, they are chiefly led by the provincial environment protection authority, instead of by the city government. The party leadership group of the provincial environment protection authority bear responsibility for nominating the head and deputy head of the city environment protection authority, for performing examinations in conjunction with the city party committee organization department, and for handing over tasks to the city party committee and government in accordance with regulatory procedures, after seeking the city party committee's opinions (Guidelines for the Pilot Program for the Vertical Management Reform of Environmental Monitoring, Inspection and Law Enforcement below the Provincial Level 2016). Although remaining as part of the working departments of the city government, the chief leaders at city environment protection agencies are nominated, approved, appointed and dismissed directly by their superior environment protection authorities at the provincial level (Zhou 2016a). 
The second change concerns the environment protection authorities at the county level. According to the Guidelines, the environment protection authorities at county levels no longer stay independent by themselves, but are included as a detached institution at the county level from the environment protection authorities at city level, with the personnel, finance and materials being integrated into their superior counterparts at the city level.

Before, Monitoring, Supervision, and Enforcement, although having been considered as the main competences of the environment protection authorities at all levels, were not discussed separately. Despite the different levels, the competences of the environment protection authorities are exactly the same (Figure 2). The Rules of Environmental Monitoring (2020) (Li 2020b) states that environment protection authorities at the central, provincial, city and county levels are to be in charge of the environment Monitoring work within their administrative jurisdictions. The function of law Enforcement is to be realized by the environment protection authorities themselves or their authorized institutions, according to Article 24 of Environmental Protection Law (Environmental Protection Law of People's Republic of China 2014). In terms of Supervision, the supervision of the governments and the relevant departments at all levels had, for a long time, been conducted by way of internal self-supervision. Since 2015, it has relied heavily on the regular inspection led by the Central leading committee of ecological and environmental protection inspection, with the issuance of the Plan on Central Environmental Protection Inspections (2015).

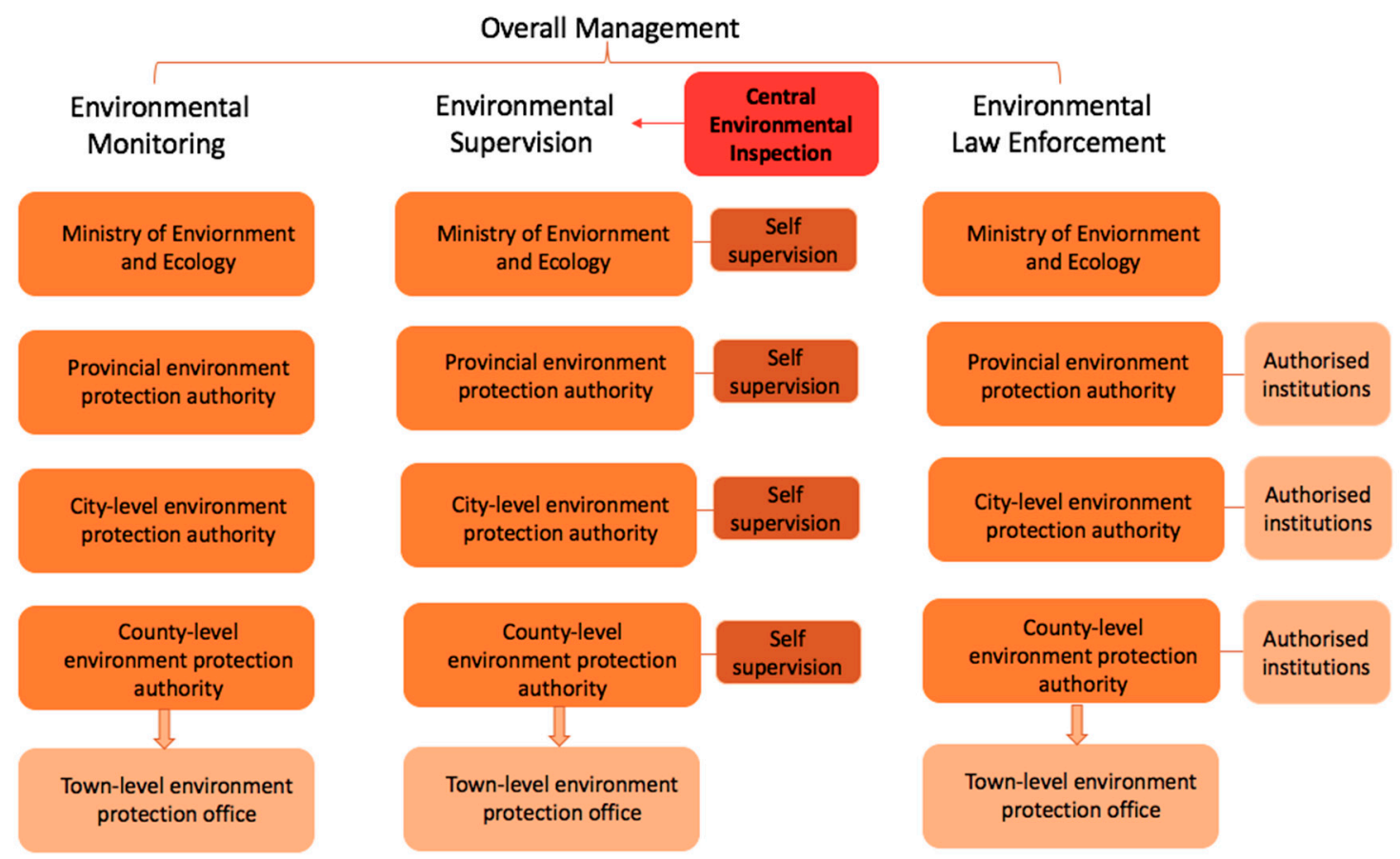

Figure 2. Structure and function of the environmental management system before the vertical management reform.

The internal allocation of power and responsibilities between the governments and environment protection authorities at different levels constitutes the core content of the environmental vertical management reform (Figure 3).

The first assumption is of environmental monitoring function at the provincial level. The Guidelines specify that the provincial environment protection authority bears the overall responsibility for environmental quality monitoring, surveying, assessment, and examination within the province, and its subordinate cities and counties. The existing monitoring functions of the city-level environmental authorities are to be implemented by the provincial environment protection authorities' detached institutions in cities, and are to be directly managed by the provincial environment protection 
authorities, which also bear responsibility for personnel and work expenses. The provincial and the detached institutions chiefly bear responsibility for ecological environmental quality monitoring work (Chen et al. 2013). The assumption of environmental monitoring functions by the superior level authority will avoid the paradoxical situation in which the authority "uses its own monitoring data to examine itself", and will ensure the validity and truthfulness of the data. This will reduce aberrant behavior in environmental monitoring, and will enable the real-time handling of monitored pollution sources and cases of ineffective environmental policy implementation (Ren 2016). Specifically, provincial environmental authorities bear responsibility for city- and county-level environmental monitoring and assessment statistics within their areas of jurisdiction, and for the unified planning and establishment of environmental monitoring networks within the scope of the province's administrative area. The provincial environment protection authorities and their detached institutions at the city level are responsible for province-wide environmental monitoring.

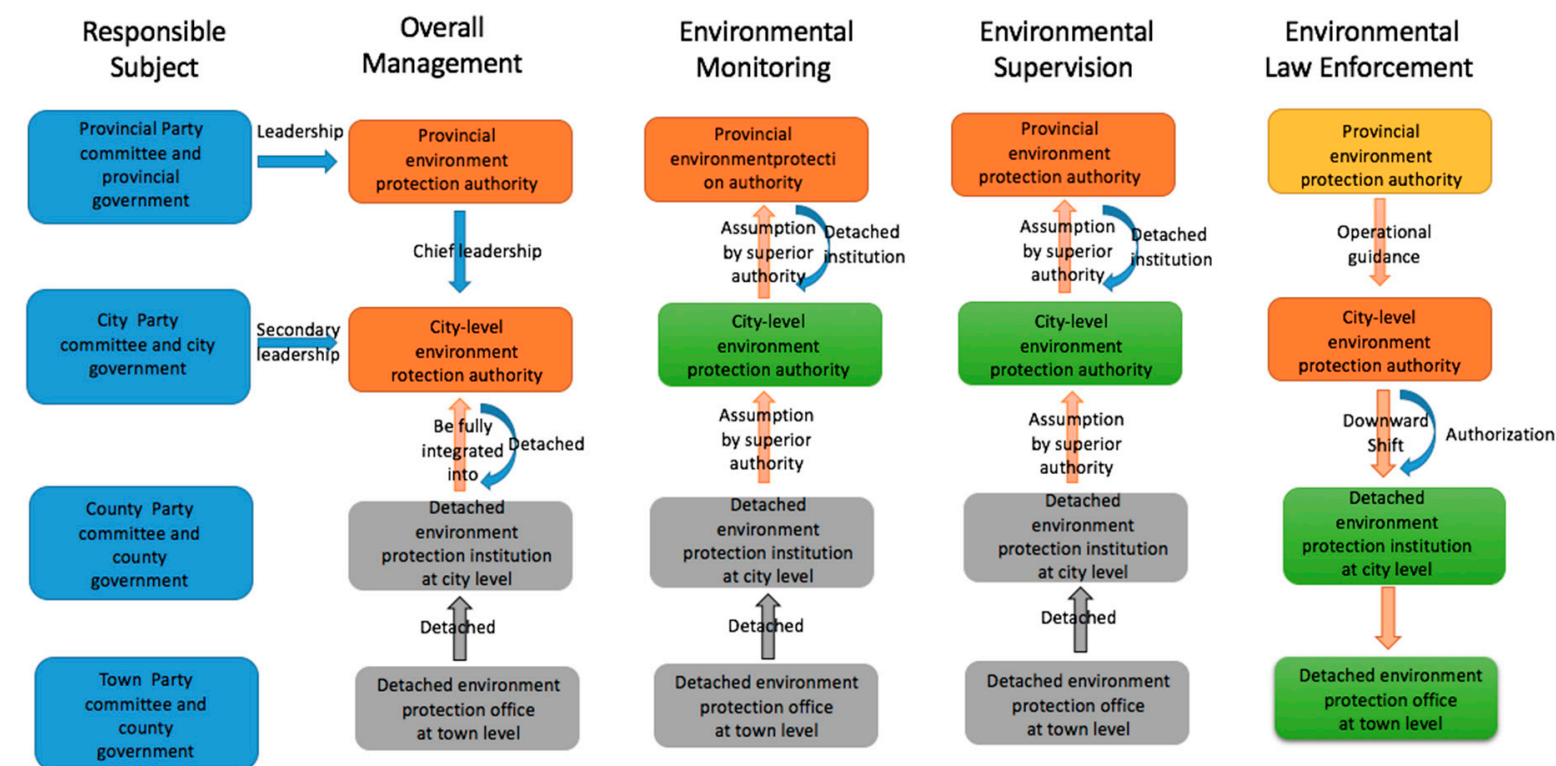

Figure 3. Structure of the environmental supervision system and the separation of the internal functions of the agencies following the vertical management reform.

The second assumption is of environmental supervision function at the provincial level. The implementation deviation of the national laws and policies by the local governments has, for a long time, been problematic for environmental governance in China (Yu and Liu 2020), therefore, vertical supervision targeting the performance of local governments is essential. The Guidelines specify that the provincial environment protection authority will assume the environmental supervision function at the city and county levels, and will implement environmental supervision through detached institutions at the city or cross-city levels. The provincial environment protection authority is authorized by the provincial government to supervise and inspect: the implementation of environmental protection laws and regulations, standards, policies, and plans; and the fulfillment of environmental protection responsibilities by city and county governments and their relevant departments within the jurisdiction. The provincial environment protection should also provide real-time reports to the provincial party committee and government (Guidelines for the Pilot Program for the Vertical Management Reform of Environmental Monitoring, Inspection and Law Enforcement below the Provincial Level 2016). Provincial environment protection authorities should implement an environmental supervision system by using a specialized on-site inspection approach, which significantly strengthens the supervision functions of the provincial environment protection authorities, force local governments to assume the major responsibility, and eliminate the local protectionism deriving from the conflict between economic development and environment protection (Wu and Qin 2016). In summary, 
provincial environment protection authorities bear unified responsibility for environmental supervision, and city-level environment protection authorities-as well as their detached institutions at the county level-are no longer empowered for environmental supervision.

The third is a downward shift of environmental law enforcement functions to the grassroots level. The Guidelines specify that the power and responsibility of environmental law enforcement will be shifted downward to the city, county and town levels, in conjunction with the enhanced establishment of grassroots law enforcement teams and strengthened environmental law enforcement within the teams' areas of jurisdiction. City environment protection authorities bear responsibility for law enforcement, and will provide unified direction for county-level environmental law enforcement forces within their areas of jurisdiction while being in charge of the latter's personnel, finance and materials. The environmental protection authorities in charge of law enforcement will be granted the wherewithal and methods needed to implement on-site inspections, administrative penalties, and administrative coercion, etc. Environmental law enforcement personnel will be included as part of the local government's administrative law enforcement personnel, and will be given the uniforms and equipment needed for investigations and for evidence collection (Guidelines for the Pilot Program for the Vertical Management Reform of Environmental Monitoring, Inspection and Law Enforcement below the Provincial Level 2016). The downward shift of environmental law enforcement to the grassroots levels will be accompanied by the transfer of the overall command of environmental law enforcement to environment protection authorities at the city level, which will reduce local governments' interference in their decision-making (Chen 2016b) and strengthen environmental law enforcement within their jurisdictions. Under such circumstances, the provincial environment protection authorities will only serve to provide guidance to city-level environment protection authorities and their detached institutions. However, they will be in charge of investigating and handling the inter-city disputes and major cases.

The following table (Table 2) illustrates the chief competences of the environment protection authorities at province, city, county and town levels under the reform.

Table 2. Chief competences of the environment protection authorities at various levels after the environmental vertical management reform.




Lastly, a mechanism of the 'co-responsibility of party and government' should be implemented to guarantee the fulfillment of responsibility of governments and their relevant departments at all levels, according to the Guidelines. The mechanism of 'co-responsibility of party and government' calls for the strengthening of the environmental responsibilities of local party committees, as well as governments at various levels, assigning chief responsibilities to the main leadership members of party committees and governments, and prioritizing the state of the ecological environment quality as a core index for the evaluation of their performance. Such an 'environmental cadre evaluation' system began during China's 11th five-year plan (2006-2010), and was considered to be a tool for limiting the risks to the party-state's hold on power (Wang 2013a). In applying the mechanism of 'co-responsibility of party and government', the role of the CPC should be particularly emphasized (Chen 2018), because the party and government system with the CPC as the core leadership of China's contemporary political system, and the integration of CPC's political will and government activities are the keys to understand the logic of China's state governance (Jing et al. 2016). The strict top-down organizational system of the CPC could be relied on to force the local governments to fulfill their responsibilities in an institutionalized, systematic, and lasting manner (Qie 2016).

\subsection{Local Practice}

At present, 24 provinces and municipalities have completed plan drafting and implementation tasks, and five provinces and municipalities have established leadership committees for environmental vertical management reform at the provincial level (Central Party School "Ecological Civilization Construction" Research Topic Group 2018), essentially completing the environmental vertical management reform ( $\mathrm{Li}$ 2020a). Apart from the 12 provinces-including Hebei, Chongqing, Jiangsu, Shandong, Hubei, Qinghai, Shanghai, Fujian, Henan, Guizhou, Guangdong—serving as trial locations, another 12 provinces_-including Jiangxi, Guangxi, Shanxi, Inner Mongolia, Yunnan, Sichuan, Beijing, Heilongjiang, Liaoning, and Hunan-have already completed the plan drafting and implementation tasks. Guangdong, Guizhou, Anhui, Ningxia, and Jilin have established vertical management reform leadership groups for environmental monitoring and supervision law enforcement below the provincial level. The following phenomena could be observed from the current local reform practices.

Firstly, most provinces have promoted the reform whilst taking account of their local realities, without strictly following the Guidelines. For instance, with regard to the adjustment of the environment protection authorities, the municipalities of Chongqing, Shanghai, and Beijing have made their county-level environment protection authorities subject to dual management, chiefly led by the city-level environment protection authorities, while leaving the county-level authorities remaining as working departments of the county government (Mi 2019). With regard to environmental law enforcement, in addition to strengthening the law enforcement personnel at the county and town levels, provinces including Guangdong and Zhejiang have established dedicated environmental police squads (Dong and Gao 2018).

Secondly, some provinces have set up platforms of joint discussion and decision-making in order to enhance the coordination between various departments and regions. Over 20 provinces have established provincial, city-level, and county-level environmental protection committees/councils, which are headed by the chief responsible personnel from the party committee or government at the same level, in order to strengthen the planning and coordination addressing inter-regional and inter-basin environmental protection problems within the province (Zhou and Ji 2020).

Thirdly, apart from setting up detached institutions for supervision, special environment inspectors have also been sent to supervise the daily performance of local governments and relevant departments. Hubei has set up five inter-regional supervision institutions in the province (Government of Hubei Province 2019). Chongqing has also issued regulations, including a list of responsibilities and accountabilities, in order to realize the fulfillment of the clarifying, following up on, and discharging mechanism of the responsibility (Chongqing Environmental Protection Work Responsibility Regulations (Trial) 2016). 


\subsection{Achievements of the Reform}

The achievements of the vertical management reform include the essential realization of the reform goals, and they specifically include the following aspects.

Firstly, the reform has effectively blocked the local interference by adjusting leadership relationships between environment protection authorities at the provincial, city, and country levels, and by adjusting the transfer of environmental monitoring and supervising powers to higher levels. Environmental vertical management reform has also dramatically changed the prevailing situation in which the personnel at environment protection authorities felt secure in their positions only when they turned a blind eye to the environmental abuses approved by local leaders and effectively eliminated interference with environmental protection motivated by local protectionism (Sun 2018). Taking Hebei as an example, after the environmental vertical management reform, the province investigated and prosecuted a number of large and important cases that the local environment protection authorities had previously failed to investigate or prosecute (Qie 2016).

Secondly, the reform has raised the veracity of the environmental monitoring data. The transfer of environmental monitoring powers to a higher level and the cross-checking of the monitoring data from provincial environmental monitoring centers in cities have reduced local government and enterprise tampering with environmental monitoring data, and the forging of monitoring data by local environment protection authorities, and it has eliminated the past practice of self-examination by the party providing the data. Taking Hebei as an example, in implementing the requirements of the reform, 468 monitoring personnel were reassigned to the provincial agency, 11 persons were assigned to monitoring centers in cities, and 194 additional county-level air monitoring stations were established, which signified that each of the 168 counties, districts, and cities in the province is equipped with two monitoring locations, in order to ensure the accuracy and integrity of the data (Guo et al. 2017).

Thirdly, the reform has enhanced the efficiency and effectiveness of environmental law enforcement. The reform has reinforced law enforcement's responsibilities and capabilities at the grassroots level by increasing the size of environmental protection teams and the funding for law enforcement activities (Central Party School "Ecological Civilization Construction" Research Topic Group 2018), and provincial and city-level environment protection agencies are now able to perform large-scale, unified cross-enforcement investigative activities (Xiong 2019). In Hubei's case, the provincial detached institutions at the city- and county-levels now have a total permanent staff of 2197 persons, of whom 1882 are subject to management in accordance with the Civil Servants Law, and 315 constitute utility staff (Government of Hubei Province 2020). The identification as permanent staff has enhanced the sense of professional identity and stimulated working enthusiasm, thus demonstrating a significant increase in overall environmental law enforcement strength.

Fourthly, the reform has provided a resolution of inter-regional and inter-basin environmental pollution problems. Taking the Guangxi Zhuang Autonomous Region as an example, the watershed environmental management offices have been established and attached to the detached interregional environmental supervision institution, enabling the overall planning of environmental management work for those watersheds within the offices' areas of jurisdiction. In particular, the Nanning ecological environmental supervisory commissioner's office has added a Zuoyoujiang watershed ecological environmental management office, the Liuzhou ecological environmental supervisory commissioner's office has added a Hongshui River and Lijiang River watershed ecological environmental management office, the Wuzhou ecological environmental supervisory commissioner's office has added a Xijiang River watershed ecological environmental management office, and the Beihai ecological environmental supervisory commissioner's office has added an office of the watershed ecological environmental management of rivers into the sea. The establishment of such inter-regional and inter-basin institutions has clarified the duties of the provincial and city-level governments with regard to inter-regional and inter-basin problems, has facilitated the overall planning of monitoring and law enforcement strength in different regions and river basins, and has resulted in improvements in the environmental management system (Tan 2018). 


\section{Discussion: Problems Currently Affecting the Effectiveness and Sustainability of the Environmental Vertical Management Reform}

The environmental vertical management reform has now been implemented for four years. As envisioned by the designers, the reform should facilitate the clarification of the powers and accomplishment of responsibilities in environmental protection, facilitate the coordination of the various parties in order to pool efforts, and facilitate a stable transition between the traditional and new environmental protection systems ( $\mathrm{Li}$ 2016). Despite the current achievements that were discussed above, problems impeding the effectiveness and sustainability of the reform still exist. This section will thoroughly investigate the existing problems.

\subsection{Lack of a Legal Basis for Organizational Adjustment under the Reform}

The Organic Law of Local People's Congresses and Local People's Governments at All Levels (shortened below as Organic Law), which provides statutory principles for state organizations, is not only the basis for organizational legitimacy but can also effectively control organizations' self-replication and curb the arbitrary establishment, modification, and abolishment of organizations. In other words, by prescribing that major actions affecting state organizations and authorities, such as their establishment and modification, must be conducted in accordance with lawful methods, the Organic Law can restrain organizations from arbitrary self-empowerment and self-replication (Wang 2018). Thus, as a document of reform, the Guidelines themselves could not replace the Organic Law and serve as the legal basis for the organizational adjustment.

While the reform involves the establishment, reorganization, modification, and adjustment of government authorities at the provincial, city, and county levels, we found that there is no legal basis for changes in organizations and authorities, the assignment of duties and powers, and the vertical and horizontal relationships in most provinces and municipalities, with the exception of Chongqing, Shandong, and Sichuan, which have used their local legislative powers to regulate the government authorities involved in the reform. The lack of a legal basis thus constitutes a risk of the unsustainability of the organizational adjustment, which provides the pre-conditions for the vertical management reform.

\subsection{Obstacles in Realizing an Effective Supervision under the Reform}

4.2.1. Conflicts with the Current Laws and Lack of Clarification on the Competence and Procedure of Supervising Work

The aim of assuming the competence of supervision at the provincial level is to realize a forceful supervision of the power and the performance of the governments and their relevant departments at various levels by relying on the authority from a superior level, thus resolving the problems of the previous self-supervision system, such as weak supervision strength, inadequate supervision effects, and insufficient supervision or even the absence of supervision. According to the Guidelines, the provincial level environment protection authorities and their detached supervising institutions are to assess and supervise the environmental protection law enforcement and performance, and the fulfillment of the responsibilities of the governments and relevant departments at the city, county, and town levels. Here, the inferior governments and their relevant departments are all included as the targets of supervision.

Article 67 of the Environmental Protection Law provides that the governments at higher levels, and the environment protection authorities thereof, are to strengthen the supervision over the environmental protection work of the governments at lower levels and the relevant authorities thereof responsibility (Chongqing Environmental Protection Work Responsibility Regulations (Trial) 2016). In practice, Article 67 is typically interpreted as 'double line' supervision (Legislative Affairs Committee of the Standing Committee of the National People's Congress 2014), indicating that the higher-level governments supervise the lower-level governments, and the higher-level environment protection 
authorities supervise their lower-level counterparts. In this case, the supervision from the provincial environment protection authorities of the inferior local governments (including inferior environment protection authorities and other departments of local governments) that is designed by the Guidelines lacks legality under the current Environmental Protection Law, because Article 67 of the Environmental Protection Law does not authorize the provincial environment protection authorities to supervise other departments of local governments. Without the power of supervising the inferior local governments, the expectation of the removal of the local governments that interfere with environmental protection decision making will be difficult to satisfy.

In addition to the conflicts with the current law, the lack of clarification on the competence and working procedure of supervision also constitutes a substantial obstacle to the achievement of effective supervision under the reform. During the interviews with five officials from the detached supervision office- one of the five cross-city detached supervision offices established by the provincial environment protection authority of Hubei-all of them expressed their confusion and worries regarding how to actually conduct the supervision work, as they could not find any substantial and procedural details, such as the selection of supervising targets and issues, the start-up, the method, the power of punishment, the appeal, and the reconsideration, etc., neither from the Guidelines, nor from the existing laws and regulations (Interview with He 2019a; Interview with Hou 2019; Interview with Li 2019a; Interview with Zhang 2019; Interview with Li 2019c).

Certain officials also indicated that there existed great difficulty in differentiating their duties and responsibilities with other similar supervising powers, particularly the national supervising committees at the local levels under the National Supervision Law (2018), and the Central Environmental Protection Inspections led by the State Council and the Ministry of Ecology and Environment. The adequate legal basis and specific working procedures for both the National supervision and the Central Environmental Protection Inspection made the status of environmental supervision under the reform more embarrassing. This is a common phenomenon in most provinces (Sun 2016b), leaving the current supervising institutions as being sometimes impractical in practice (Sheng and Sun 2016).

\subsubsection{The Overlapping Accountability}

Taking the local governments and their relevant departments as targets for supervision is an original innovation of the reform. Article 26 of the Environmental Protection Law provides that the state is to apply an objective responsibility system, and an evaluation and review system to environmental protection. The government at and above the county level are to include the achievement of environmental protection objectives in the evaluation of their respective departments with environmental protection supervision and administration functions, and the persons in charge thereof-as well as the governments at the lower levels and the persons in charge thereof-as an important basis for their evaluation and review. In practice, this objective responsibility system and an evaluation and review system formed a concrete assessment and evaluation system encompassing individual areas, such as the atmosphere, water, soil, and reductions in chief pollutant emissions (Chen 2017).

Since 2015, with the issuance of the Plan on Central Environmental Protection Inspections (2015), the inspections led by the Central leading committee of the ecological and environmental protection inspection have largely reinforced the strength of such supervision. The Working Rules on the Central Ecological and Environmental Protection Inspections, published in 2019, further normalized this form of supervision.

The common goals, supervising targets, and methods of accountability of these two existing supervision systems have already resulted in possible overlapping accountabilities. Now that the supervision under the vertical management reform coincides significantly with the accountability as defined in the Environmental Protection Law and the Central Environmental Protection Inspection, this has resulted in a tendency toward 'inspection by multiple agencies' and 'overlapping accountability', and has caused unnecessary interference in the day-to-day work of local governments and their relevant 
authorities. Large amounts of time and energy can be spent on the various inspections and evaluations, thus distracting the authorities from concentrating on their own duties (Ge et al. 2016; Wen and Li 2019).

\subsection{High Risk of Unsustainability with Regard to the Implementation of the Reform at the County Level}

\subsubsection{Conflicts between the Guidelines and Environmental Protection Laws and Regulations}

Article 24 of the Environmental Protection Law provides that the environmental protection authorities of the people's governments at and above the county level, as well as the institutions authorized by them and other relevant authorities, are to have the authority to conduct the on-site inspection of enterprises, public institutions, and other businesses that discharge pollutants (Environmental Protection Law of People's Republic of China 2014). Article 25 provides that, where the discharge of pollutants by enterprises, public institutions, and other businesses in violation of the laws and regulations has caused, or may cause, any serious pollution, only the environment protection authorities themselves and other relevant authorities at and above the county level, and other departments with environmental protection administration functions, may seize or impound the facilities or equipment causing the discharge of the pollutants. In addition, Articles 29, 60, 61, 62, and 63 also exclude the authorized institutions and other relevant authorities from making administrative punishment decisions, such as imposing continuous fines, restricting production, suspending businesses for rectification, terminating businesses, closing down businesses, ceasing construction, ordering restoration to the original state, and detaining the directly liable person, etc., making the environment protection authorities the only ones who can issue these orders (Environmental Protection Law of People's Republic of China 2014).

However, according to the Guidelines, the environment protection authorities at the county-level no longer constitute "county-level government environmental protection administration competent authorities" but must be integrated into their counterparts at the city level as detached institutions. With no explicit authorization from the environmental protection laws and regulations, nor from the environment protection authorities at the city levels, these detached environmental protection authorities at the county level cannot be a subject of administration, and cannot exercise the unified environmental management duties explicitly specified in the environmental protection laws and relevant regulations. Therefore, the downward shift of the function of law enforcement to the county and town levels cannot be realized. The activities conducted by the detached authorities at the county and town levels further face the potential high risk of illegality.

4.3.2. Conflicts between the Environmental Vertical Management Reform and the 'Super-Ministry System' Reform at the County Level

The 'super-ministry system' reform, which was initiated in 2012, required that the environment protection authority at various levels integrate the competences of other relevant authorities (water, forest and grassland, land, natural resources, etc.) related to environmental protection in order to become a complete 'super environment protection authority' (Editor's Office 2018). However, given that under the environmental vertical management reform, the 'super environment protection authority' no longer exists, should the competences that have been integrated into the super authority from other relevant authorities also be transferred to the city-level environment protection authority, or should they be given back to their original authorities, as these authorities still exist as a part of the county-level government?

Such conflicts occur in practice. For example, in implementing the 'super-ministry system' reform (Zhao 2018) in 2012, the city of Guiyang set up its Super Environment Protection Authority at the county level—called the Committee of Ecological Civilization Promotion—by replacing the original Environment Protection Bureau, Forest Administration Bureau, and Water Administration Bureau as well as integrating some competences from other relevant authorities, such as construction, transport, industry, and communication, etc. (Ren and Lei 2016). Since then, the Forest Administration Bureau and the Water Administration Bureau have no longer existed at the county level. In the process of the 
environmental vertical management reform, starting in 2016, the county-level committee of ecological civilization promotion turned into a detached institution of the city-level committee of ecological civilization promotion, with its integrated competences from the original forest administration bureau and water administration bureau being included in the vertical management system. Under such circumstances, the county government is no longer in charge of the personnel, finances, and materials in the field of forest and water management, and the forest administration bureau and water administration bureau at the city level have no counterparts at the county level.

4.3.3. Difficulties for the Detached Environment Protection Institutions in Participating in Environmental Decision-Making at the County Level

In order to strengthen the environmental protection work within the environmental protection target responsibility system provided by Article 6 of the Environmental Protection Law (Environmental Protection Law of People's Republic of China 2014), a county-level government must depend on its environment protection authority to perform various important tasks, including environmental planning, total emissions control, and environmental impact assessments. In the case that the environment protection authority at the county level is replaced by the detached environment protection institutions from the city level, county-level governments cannot fulfill their environmental protection target responsibilities without a provider for these services. This will objectively weaken their management capabilities in environmental affairs, which will bring about a reduction in the county governments' ability to bear total responsibility for the environmental protection within their respective administrative regions.

On the other hand, as the county environment protection authority constitutes an institution that is detached from the city-level environment protection authority instead of being a part of the county-level government, it cannot effectively participate in the environmental decision-making process within the county, nor the formulation of the local economic and social development plan, which may create a new obstacle for the mechanisms coordinating the 'multiple planning integration' of environmental plans with various local plans. Although some provinces have set up environmental protection committees at the county level, barriers remain in maintaining the coordination while rationally assigning the responsibilities between the existing detached environment protection institution and the newly-established environmental protection committee.

4.3.4. Lack of Self-Regulation for the Detached Environment Protection Institutions at the County Level

The supervision of the detached institutions at the county level depends heavily on internal supervision by the city-level environment protection authorities. As they no longer belong to the county government, the authorities-such as the local people's congresses and governments at the county level -lack a basis for supervision. Additionally, the internal supervision by the city-level environment protection authorities consists largely of operational management and guidance, and focuses chiefly on the operating performance, while possibly neglecting the management of the detached institutions' other aspects. As the activities of the detached institutions take place locally, it is difficult to supervise them in real-time, resulting in a considerable risk of local corruption (Zhang et al. 2017).

\section{Recommendations for the Realization of Effective and Sustainable Environmental Management}

The Ministry of Ecology and Environment required the full completion of environmental vertical management reform by 2020 ( $\mathrm{Li} 2020 \mathrm{a}$ ). For the next stage, the focus of environmental vertical management will shift to addressing the current challenges in order to enhance the effectiveness and sustainability of the reform, enabling the government at all levels to play larger and even more effective roles in environmental governance. 


\subsection{Firmly Promoting the Rule of Law in the Process of Implementing the Reform}

The promotion of the reform and the promotion of the rule of law have been the two pillars of China's economic and social development since the reform and the opening-up policy in the late 1970s (Li 2018). However, the balance between the reform and the rule of law can be a delicate issue as, generally, the reform represents change and innovation, while the rule of law requires normalization and stability (Chen and Zhang 2017). As can be observed from the local practices of implementing the environmental vertical management reform, the risk of the illegality of the reform exists with the lack of legal basis and the conflicts with the current laws and regulations.

However, ensuring a clear and solid legal basis for all of the details of the reform is not only unrealizable but also unnecessary. In China, going through a pilot reform at local levels before finally being written into national laws and regulations is a common trajectory in the formation of a new system (Su and Wang 2016). In the present trial stage, the experience and lessons are very likely to be absorbed in order to adjust the policies in a flexible way and to help formulate the laws and regulations in the future. In other words, sometimes the space of trial and error is left intentionally for further policy adjustment before the process of legalization, thus tolerating the temporary inconsistencies between the reform and the laws.

Nevertheless, significant illegality and conflict are intolerable, under the requirement that significant reforms should definitely be based on laws (Li 2019b). This is the case of current environmental vertical management reform, as it touches several fundamental changes, for example, the institutional and personnel changes, as well as the allocation of power and responsibilities among the different government levels. However, the problem of who could judge and who could challenge the illegality and conflict exits. The Administrative Litigation Law excludes the complaints field of citizens, legal persons, or other organizations against the administrative regulations and rules or decisions and orders with general binding force developed and issued by administrative agencies out of the scope of cases accepted by the courts. The nature of the Guidelines further complicates the problem. As a document jointly issued by the General Office of the Central Committee and the General Office of the State Council, it could hardly be simply regarded as administrative regulations and rules, or decisions and orders. Under such circumstances, the public would have no access to challenge the illegality and conflict between the reform and the current laws until the pilot systems and institutions of the reform could finally be legalized by law amendments.

Priority should be given to two aspects. First, in terms of the organizational and personnel adjustment, the power of adjusting the administrative authorities belongs to the state, and should be realized through the amendments of the Constitution and relevant laws, according to the Organic Law (Qiao 2016). Local governments and the relevant environment protection authorities should obtain explicit authorization from the laws to set up new authorities or institutions, or to change the attributes of the current authorities. Secondly, explicit authorization to conduct administrative activities, such as inspections and the imposition of punishment, should also be given to the detached environment protection institutions at the county and town levels, either through amendments to the Environmental Protection Law or by the environment protection authorities at the city level.

In addition, matching systems related to the environmental vertical management reform should be established in the form of laws or regulations, particularly for environmental supervision. Emphasis should be placed on the specification of the nature of the supervising power and the procedure of conducting supervision under the reform, as well as the coordination and cooperation with the national supervision and similar environmental supervising systems, such as the objective responsibility system, an evaluation and review system, and the central environmental protection inspections, in order to ensure that the different systems are coordinated and consistent and avoid redundancies (Zhao and Li 2018).

Finally, it is expected that all of the positive changes deriving from the reform should be included into laws and regulations in the near future, so that the achievements of the reform can be consolidated and possible backsliding can be prevented. 


\subsection{Enhancing the Institutional Supply and Capacity Building at the Grassroots Levels}

Many expectations have been placed on the primary levels under the reform in the aspect of promoting environmental law enforcement. This reveals the principle of localized environmental governance (Zhang 2020), which is highly praised worldwide. Indeed, compared with the central government and the superior local governments, the governments and detached institutions at the county and town levels have direct access to the individuals and enterprises within their respective administrative regions, enabling them to be aware of the demand and expected benefits of the public and society (Chen and Tang 2020). Additionally, through daily observation, self-learning, and frequent communication with local citizens, officials located at the primary levels can become acquainted with the local situation and are equipped with local knowledge, thus making them a bridge between the superior governments and the public (He 2018), and making them a coordinator of the implementation of the national laws and policies in an adaptive way (Feng 2020).

The transfer of law enforcement power from the superior levels to the primary levels is an important step toward a much more localized and effective environmental management system. Furthermore, the designer of the reform considered the risk of local protectionism by setting a detached environment protection institution at the county level, replacing the original county-level environment protection authority as a department of the county-level government. Under the traditional bureaucracy of a strict hierarchy, a detached institution from the superior government has relatively more power over the environmental protection affairs, thus canceling the interference pressure from the county government.

However, institutional loopholes remain in terms of the lack of supervision over the detached institutions, and the disconnect between the detached institutions and the county governments. On the one hand, the regular supervision of the detached institution should be conducted by the city government and its environmental protection authority. The National People's Congress and the Chinese People's Political Consultative Conference of the city level should enact these localized detached institutions as key supervising targets. The public, including the non-governmental organizations, should be mobilized as external supervision. External supervision could be realized through reporting to the supervision institutions and the administrative litigation. The former way seems to be more realizable and common due to the limitations on the standing of administrative litigation according to the administrative procedural law. In order to encourage the citizens, legal persons and other organizations that discover any environmental pollution or ecological damage caused by any entity or individual, or any failure of the local governments at any level to report to the relevant government departments or to the superior levels and supervision institutions, Article 53 of the Environmental Protection law provides that the environment protection authorities and other departments with environmental protection management functions are to disclose environmental information and improve the procedures for public engagement (Environmental Protection Law of People's Republic of China 2014). On the other hand, a cooperative working mechanism should be set up between the detached environment protection institution and the county and town governments, as cross-department cooperation is indispensable in the process of environmental law enforcement. In practice, at the local level, the environmental protection committees could serve as a platform for such cooperation.

The environmental protection committees were established in order to realize the performance of environmental protection functions by local governments, and to compensate for the lack of independent county-level environment protection authorities following the transfer of their administrative powers to the city level. The unified exercise of environmental management coordination powers by environmental protection committees can therefore help to achieve the prompt coordination and resolution of conflicts and inconsistencies between the detached institution and the local government. Environmental protection committees can also confirm the organization of various relevant departments, clarify each department's responsibilities in environmental protection work, rationalize different departments' relationships, assign initiatives in environmental protection work, and establish local environmental protection work systems with coordinated unified management and the division of responsibilities (Chen 2016a). 
The transfer of power and responsibility is far from enough; priority should be given to the transfer of capacity. Environmental law enforcement personnel at the primary levels constitute the most fundamental and basic supporting strength needed to perform government environmental protection duties. Efforts should be made to further increase the legal awareness of environmental law enforcement personnel, and to strengthen their professional knowledge and skills training to boost their mastery of environmental protection laws and regulations, and their familiarity with other relevant laws and regulations. More professional personnel with a command of advanced and new technologies should be recruited in order to enhance specialized skill levels. Environmental law enforcement facilities should be improved, and, most importantly, the funding inputs for environmental law enforcement should be increased. Environmental law enforcement work tends to be highly technical and specialized, meaning that the government should increase funding, encourage the input of social capital, and improve the fiscal guarantee system for law enforcement funding. The government could also consider using a certain percentage of pollution emission fees and environmental protection taxes to provide the funding needed for environmental law enforcement. The central and superior governments should additionally increase budgetary support for grassroots environmental law enforcement in order to ensure that the law enforcement personnel at the front lines possesses advanced equipment and instruments, to ensure that the law enforcement personnel at the front lines enjoy standardized personnel establishment management and guaranteed salaries, and to guarantee the accuracy, timeliness, and scientific basis of environmental law enforcement.

\subsection{Taking the Advantage of Holistic Governance under the Leadership of the CPC}

There are two systems of decision-making and executing mechanisms in contemporary China: the governmental frame stipulated by the constitution and the Party frame stipulated by the Party constitution. In practice, the system of government and the system of the CPC are not run separately and independently. More specifically, the two systems are closely interconnected with each other under the condition that they both follow the centralized and unified leadership of the CPC (Wang and Tang 2019). The legitimacy of this combined structure of government and party comes from the Constitution, stating in Article 1 that the leadership of the CPC is the defining feature of socialism with Chinese characteristics (Constitution of People's Republic of China 2018).

The superiority of this structure is embodied in a holistic governance structure at the national level, using a highly integrated and unified Party system (Huang 2020) to overcome the fragmented bureaucracy and departmentalism (Wang and Deng 2011) of the government system. On one hand, in the process of policy making, the CPC as the nation-wide ruling party can jump out of the shortsighted departmental and local interests by formulating policies that are in line with the overall and long-term interests; on the other hand, in the process of implementation, the CPC can promote policy implementation in an efficient, effective, and flexible (He 2019b) manner, relying on the national linkage network and strict discipline rules (Su 2016). This explains why most reforms, policies, and even laws and regulations are initiated by the Central Committee of the CPC, and why the local governments react rapidly and the governance effectiveness occurs in the short term in the case of the top-down forcing by the CPC.

The combined structure of the government and Party places the government officials under the Party's overall management and supervision, with the Party substantially deciding their appointment, promotion, and removal (He et al. 2014). This is the key to understanding the vertical management system in all of the areas of China (O'Brien and Li 1999; Zhou 2008), and it has provided the basis for the mechanism of the 'co-responsibility of the Party and government' under the environmental vertical management reform (Zhou et al. 2005).

Consequently, in order to realize the fulfilment of the local governments' responsibilities and to guarantee an effective and sustainable implementation of the reform, the forcing power (Xiong 2019) of the Party system should be used, and the advantage of holistic governance under the leadership of CPC should be taken. Specifically, first, matching systems related to the environmental vertical 
management reform should be drafted jointly by the State Council and the Central Committee of the CPC. Relevant inner-Party rules should be established in order to reinforce the fulfilment of the Party's responsibilities at all of the levels of environmental protection. Second, the internal supervising power of the Party should be used to avoid law and policy implementation deviation at the local levels.

Therefore, the details of the 'co-responsibility of the Party and government' should be defined in terms of how the supervising and accountability procedure is initiated, the collaboration of the two systems, and the clarification of the responsibilities. Third, in order to help reinforce the environmental law enforcement capacity, priority should be placed on the primary levels-which are the weak zones of the government system-by making full use of the ability of the grassroots Party organizations to mobilize the various resources and the public.

It is worth noting that the operation of the combined structure of the government and the Party should be under the premise of the rule of law. Taking advantage of holistic governance under the leadership of CPC does not mean replacing the local governments; therefore, interference from the local Party organizations in the local government's daily operations should be contained.

\section{Conclusions}

In contrast to the previous implementation of the local environmental vertical management reform at widely dispersed trial points, due to its vast scope (nationwide promotion), depth of implementation (including the adjustment of agencies, personnel affairs, authority, and finances), and broad reach (including law enforcement, monitoring, and supervision), the current round of environmental vertical management reform constitutes substantial progress toward the institutional reform of China's environmental governance. However, in its examination of the current local practices and the occurring challenges, this paper argues that a high risk of ineffectiveness and unsustainability exists, potentially even turning the reform into a form of trouble in itself.

Systemic reform will take time and effort. Old precedents must be overturned, adaptations must be made to new systems, and continuing systemic guarantees and reforms must be established. These are aspects that the current environmental vertical management reform is still lacking.

There are also various challenges that threaten to derail the continued implementation of environmental vertical management reform: (1) the first is the continuing tension between the reform and the rule of law. While the reform may be shifting and unstable, the strengthening of the rule of law is an essential long-term strategy. (2) The law enforcement capabilities at the grassroots level to support a vertical management model are still very weak. In comparison with the shifting of manpower and funding downward to the grassroots level, the shifting of law enforcement capabilities downward will be key to successful reform. (3) The vertical management model is not fully compatible with the existing bureaucratic system and the super-ministry system reform. The reform is a system-wide undertaking; individual reform must not conflict, and must instead be coordinated with existing institutional systems and other reform results if it is to be sustainable. (4) The ways in which to take advantage of the combined structure of the government and the Party while maintaining the independence of the local governments is another challenge. Further research is needed if environmental vertical management reform is to provide a way forward for China's environmental management system.

Funding: This research received no external funding.

Conflicts of Interest: The author declares no conflict of interest.

\section{References}

O’Brien, Kevin J., and Lianjiang Li. 1999. Selective policy implementation in rural China. Comparative Politics 31: 167-86. [CrossRef]

Cai, Fei, Xuan Li, and Xiaoyue Shen. 2015. Performing the broad-based strengthening of the environmental management system through authoritative actions. China Environment News. April 3. Available online: http://www.chinanews.com/ny/2015/04-02/7179336.shtml (accessed on 17 June 2020). (In Chinese) 
Central Party School "Ecological Civilization Construction" Research Topic Group. 2018. Reform thinking concerning the establishment of monitoring, supervision, and law enforcement vertical management systems at environment protection agencies below the provincial level (关于实行省以下环保机构监测监察执法垂直 管理制度改革的思考). Theoretical Horizon.

Chen, Guozhi. 1999. Several issues concerning the vertical management reform in market regulation (工商行政管 理体制垂直改革后应当注意的几个关系问题). Research on China Market Regulation 4.

Chen, Jian. 2008. The historical role and present limitation of the tournament system (晋升锦标赛的历史作用与现 实局限). Journal of Guangzhou University (Social Science Edition). [CrossRef]

Chen, Huaxun. 2016a. Thoughts about environmental vertical management system reform (关于环保垂直管理 制度改革的思考). China Environment News. December 28. Available online: https://www.cenews.com.cn/ opinion/rdjd/201612/t20161228_813771.html (accessed on 16 October 2020). (In Chinese)

Chen, Jilin. 2016b. Eliminating Interference in Environmental Supervision and Law Enforcement from Local Protectionism. Xinhuanet.com. March 11. Available online: http://www.xinhuanet.com/politics/2016lh/201603/11/c_135178010.htm (accessed on 1 September 2020). (In Chinese)

Chen, Huaxun. 2017. Legalization of Environmental Supervision System: Position, Dilemma and Way-Out (环保督 察法治化: 定位、困境及其出路). Law Review. Available online: https://www.sohu.com/a/168282682_671251 (accessed on 14 October 2020). (In Chinese)

Chen, Haisong. 2018. The party, state and society in China's environmental rule of law (中国环境法治中的政党、 国家与社会). Chinese Journal of Law.

Chen, Shixiang, and Yuzhen Tang. 2020. Historical changes and improvements in the allocation of power and responsibilities between the central and local governments (中央-地方政府间职责结构的历史变迁与优化). Administrative Forum 2: 41-49.

Chen, Kelin, and Liwei Zhang. 2017. The Conflicts between innovative reform and rule of law: Risk of corruption, internal mechanism and its governance (国家治理逻辑中地方政府的“创新-法治”张力及其后果——“系统性腐 败”的一种解释). Government Administration. Available online: http://www.doc88.com/p-19059448854978.html (accessed on 14 October 2020). (In Chinese)

Chen, Jiajian, Huimin Bian, and Xiangshu Deng. 2013. Hierarchical Structure and Policy Implementation (科层 结构与政策执行). Sociological Study No. 6. Available online: http://www.360doc.com/content/20/0205/20/ 32425336_889934443.shtml (accessed on 14 October 2020). (In Chinese)

Chongqing Environmental Protection Work Responsibility Regulations (Trial). 2016. Xinhuanet.com. November 25. Available online: http://www.xinhuanet.com/politics/2016-11/25/c_129379173.htm (accessed on 17 July 2020). (In Chinese)

Constitution of People's Republic of China. 2018. Available online: http://www.npc.gov.cn/npc/c505/201803/ e87e5cd7c1ce46ef866f4ec8e2d709ea.shtml (accessed on 15 June 2020). (In Chinese)

Ding, Yaoyao. 2016. Vertical management is a “foundational” systemic reform (垂直管理是“底盘性”制度改革). Environment Economics. Available online: http://huanbao.bjx.com.cn/news/20161110/787671.shtml (accessed on 14 October 2020). (In Chinese)

Dong, Jun, and Jing Gao. 2018. Strive to Eliminate Local Protectionism and Strengthen Grassroots Environmental Supervision Functions-Assessment of the Results of Monitoring, Supervision, and Law Enforcement Vertical Management System Reform at Environment Protection Agencies below the Provincial Level. Xinhuanet.com. May 29. Available online: http://www.xinhuanet.com/2018-05/29/c_1122906289.htm (accessed on 15 July 2020).

Eaton, Sarah, and Genia Kostka. 2014. Authoritarian environmentalism undermined? Local leaders' time horizons and environmental policy implementation in China. The China Quarterly 218: 359-80. [CrossRef]

Editor's Office. 2018. Super Ministry of Ecology and Environment: From super ministry to super environmental protection (组建生态环境部: “大部制”带来“大环保”). Environment Protection 6: 1.

Environmental Protection Law of People's Republic of China. Available online: http://www.npc.gov.cn/wxzl/ gongbao/2014-06/23/content_1879688.htm (accessed on 15 June 2020). (In Chinese)

Feng, Meng. 2020. Objective Balance and Process Control: An Analytic Framework for the Behavior Logic of Local Government Innovation (目标权衡与过程控制: 地方政府创新的行为逻辑). Sociological Studies 3: 124-45. 
Ge, Chazhong, Zhixiong Weng, and Xuetao Zhao. 2016. Environmental protection inspector: A top instrument for co-responsibility of the party and governmental officials (环境保护督察巡视: 党政同责的顶层制度). Chinese Journal of Environmental Management. Available online: http://zghjgl.ijournal.cn/ch/reader/create_pdf.aspx? file_no=20160114\&year_id=2016\&quarter_id=1\&falg=1 (accessed on 14 October 2020). (In Chinese)

Environmental Vertical Supervision System Established in Hubei. Website of the Government of Hubei. November 14. Available online: http://www.hubei.gov.cn/hbfb/bmdt/201911/t20191114_1517350.shtml (accessed on 3 July 2020). (In Chinese)

Persisting in Tackling Problems, Relying on Overall Planning to Achieve Cooperation, Promoting Substantive Province-Wide Ecology and Environmental System Reform. Hubei Ecology and Environmental Bulletin, No. 7. Hubei Provincial Government Website. June 17. Available online: http://sthjt.hubei.gov.cn/fbjd/xxgkml/ sthjtjb/202006/t20200617_2393677.shtml (accessed on 5 August 2020). (In Chinese)

Guidelines for the Pilot Program for the Vertical Management Reform of Environmental Monitoring, Inspection and Law Enforcement below the Provincial Level. Available online: http://www.gov.cn/zhengce/2016-09/22/ content_5110853.htm (accessed on 1 June 2020). (In Chinese)

Guo, Xiaocong. 2008. Centralizing and separating authorities: The basis, boundary and restriction (集权与分权: 依据、边界与制约). Academic Research. [CrossRef]

Guo, Zhijin, Mengxi Xu, Yan Lin, Mu Shu, and Gulong Lin. 2017. What Are the Results of Environmental Vertical Management Reform? Listening to Representatives' Explanations at the 19th National Congress. CRNTT.com. October 24. Available online: http://www.crntt.com/doc/1048/5/4/2/104854267.html?coluid= 93\&kindid=13691\&docid=104854267 (accessed on 15 July 2020). (In Chinese)

Han, Depei, ed. A Course in the Law of Environmental Protection. Beijing: Law Press China, p. 123.

He, Yanling. 2018. The reordering of relations and the formation of a national governance structure (理顺关系与 国家治理结构的塑造). Social Sciences in China. Available online: http://www.cssn.cn/zx/201912/t20191214_ 5058755.shtml (accessed on 14 October 2020). (In Chinese)

He, Ping. 2019. Interview by Di Zhou. Semi-structured interview, Jingzhou. November 19.

He, Zhe. 2019. From hard governannce to soft governance-A trend for perfecting the state governance system (从硬治理到软治理: 国家治理体系完善的一个趋势). Administration Reform. [CrossRef]

He, Yanling, Guanglong Wang, and Shiguo Chen. 2014. A political analysis of the expenditure of municipal governments in China (中国城市政府支出的政治分析). Social Sciences in China 7: 87-106.

Hou, Minghua. 2019. Interview by Di Zhou. Semi-structured interview, Jingzhou. November 19.

Huang, Wenyi. 2020. The normative doctrines of the political-legal system in China (中国政法体制的规范性原理). Chinese Journal of Law. Available online: http://iolaw.cssn.cn/zl/mkszyfx/zypl/202007/t20200724_5160099.shtml (accessed on 15 October 2020). (In Chinese)

Jing, Yuejin, Mingming Chen, and Bing Xiao. 2016. Government and Politics in Contemporary China. Beijing: China Renmin University Press, p. 7.

Legislative Affairs Committee of the Standing Committee of the National People's Congress. 2014. Explanations on Environmental Protection Law of China; Beijing: China Legal Publishing House, p. 234.

Li, Ganjie. 2016. An Authoritative Interpretation of the "Guidelines for the Pilot Program for the Vertical Management Reform of Environmental Monitoring, Inspection and Law Enforcement below the Provincial Level". Xinhuanet.com. September 26. Available online: http://www.xinhuanet.com/politics/2016-09/23/c_ 1119616066.htm (accessed on 15 July 2020). (In Chinese)

Li, Tao. 2018. The Positive Interactions between Reform and Rule of Law in the New Era (新时代中国改革与法治 的量刑互动关系论). Jianghan Luntan. [CrossRef]

Li, Ming. 2019. Interview by Di Zhou. Semi-structured interview, Jingzhou. November 19.

Li, Tao. 2019. Reform and rule of law in contemporary China: Focused on the making of rules since the reform and opening-up of 1978 (当代中国的改革与法制——以改革开放以来法律制定的主要特点为中心). Guangdong Social Sciences 5: 235-43.

Li, Xi. 2019. Interview by Di Zhou. Semi-structured interview, Jingzhou. November 19.

Li, Ganjie. 2020a. Speech Given by the Minister of Ecology and Environment at the 2020 National Conference on Ecological and Environmental Protection. Website of the Ministry of Ecology and Environment. January 18. Available online: http://www.mee.gov.cn/xxgk2018/xxgk/xxgk15/202001/t20200118_760088.html (accessed on 5 August 2020). (In Chinese) 
Li, He. 2020b. The Ministry of Ecology and Environment Adopted the Rules of Environmental Monitoring on 21 February 2020. Xinhuanet.com. February 21. Available online: http://www.xinhuanet.com/2020-02/21/c_ 1125605616.htm (accessed on 7 September 2020). (In Chinese)

$\mathrm{Li}$, Xuan, and Xiaoyue Shen. 2011. Experiences and lessons from local institutional reforms of environmental vertical management-Survey of the results of reform of the local environmental administrative system (我国地方 环保垂直管理体制改革的经验与启示——基于地方环保行政体制改革效果的调查). Environmental Protection. [CrossRef]

Li, Hongbin, and Lian Zhou. 2005. Political Turnover and Economic Performance: The Incentive Role of Personnel Control in China. Journal of Public Economics 89: 1743-62. [CrossRef]

Li, Simin, Junhai Zang, and Shengtaoi Ye. 2012. Review on the reform of China's land management system (中国 土地管理体制改革的研究综述). Guangdong Land Science 11.

Liao, Debin, and Wu Lin. 2016. Change and development of the quality management system of environmental monitoring under vertical management system (浅谈垂管方式下环境监测质量管理体系的变化及对策). Environment and Sustainable Development 3. [CrossRef]

Ma, Lihong. 1998. On the 'block-Line' relationship in the public administration (论政府管理中的条块关系). Journal of Political Science 4.

Ma, Yun. 2017. Vertical environmental management: A panacea to the environmental enforcement gap in China? Chinese Journal of Environmental Law 1: 37-68. [CrossRef]

Mao, Xiaojun. 2019. From dual leadership to vertical leadership: The way out for fiscal vertical management reform at provincial level (从双重领导到垂直领导: 省域税务机关管理体制的最终走向). Sub-National Fiscal Research 11.

Mi, Xi. 2019. Different ways of implementing the environmental vertical management reform. China Environmental News. May 22. Available online: http://www.h2o-china.com/news/291926.html (accessed on 7 September 2020). (In Chinese)

Qiao, Xiaoyang. 2016. Harnessing legislation's leadership and promoting effect on reform. People's Daily. July 19. Available online: http://opinion.people.com.cn/n1/2016/0719/c1003-28564347.html (accessed on 13 October 2020). (In Chinese)

Qie, Jinrong. 2016. Vertical management does not change the main environmental responsibilities of party and government. Legal Daily. September 23. Available online: http://www.chinanews.com/gn/2016/09-23/ 8012142.shtml (accessed on 7 September 2020). (In Chinese)

Ran, Ran. 2013. Political incentives and local environmental governance under the authoritarian mechanism (压力 型体制下的政治激励与地方环境治理). Comparative Economic E Social System.

Ran, Ran. 2015. The Supervising Mechanism in environmental governance. Expanding Horizons, 73-77. [CrossRef]

Ren, Yong. 2016. Logic and tasks of vertical management reform. China Environment News. October 13. Available online: http://epaper.cenews.com.cn/html/2016-10/13/content_51038.htm (accessed on 17 July 2020). (In Chinese)

Ren, Min, and Lei Lei. 2016. Research on innovation of environmental holistic governance mechanism: Case study on Guiyang ecological civilization construction council (环境整体性治理机制创新研究——以贵阳市生 态文明建设委员会为样本). Journal of Fujian Administration Institute. [CrossRef]

Sheng, Shihai, and Libin Sun. 2016. Four problems to be resolved under the environmental vertical management in China. China Environment News. May 6. Available online: http://epaper.cenews.com.cn/html/2016-05/06/ content_43696.htm (accessed on 7 September 2020). (In Chinese)

Institutional Reform Plan of the State Council. 2018. Available online: http://www.gov.cn/guowuyuan/2018-03/17/ content_5275116.htm (accessed on 14 October 2020). (In Chinese)

Su, Si. 2016. Vertical management requires the clarification of four legal relationships (垂直管理要明确四个法律 关系). China Environment News. January 22. Available online: https://www.cenews.com.cn/opinion/rdjd/ 201601/t20160122_801695.html (accessed on 15 October 2020). (In Chinese)

Su, Liyang, and Yi Wang. 2016. China's central-local interaction in decision making: Based on the case study of energy-saving policy making process (中国“央地互动型”决策过程研究一一基于节能政策制定过程的分析). Journal of Public Administration.

Sun, Chang. 2016a. Reform of the Vertical Management System of Local Environmental Monitoring and Enforcement: Advantages, Impacts and the Direction (地方环境监察监测执法垂直管理体制改革: 利弊争论 与改革方向). Chinese Public Administration. [CrossRef] 
Sun, Youhai. 2016b. Promote the environmental protection vertical management system to solve the problems of local protectionism (推行环保垂直管理破解地方保护难题). Environmental Protection. [CrossRef]

Sun, Xiuyan. 2018. Stiffening the backbone of environmental protection. People's Daily. June 5. Available online: http://env.people.com.cn/n1/2018/0605/c1010-30035417.html (accessed on 5 August 2020). (In Chinese)

Tan, Xi. 2018. Thinking about vertical management reform at environment protection agencies at local levels in China (我国地方环保机构垂直管理改革的思考). Administration Reform.

Wang, Alex. 2013a. The Search for Sustainable Legitimacy: Environmental Law and Bureaucracy in China. Harvard Environmental Law Review. [CrossRef]

Wang, Jixia. 2013b. On the vertical management reform of government administration in china in a legal perspective (法治视野下的我国政府垂直管理制度研究). Hubei Social Sciences 5. [CrossRef]

Wang, Quanbao. 2013c. Institutional reform in food and drug supervision: Integration and decentralization (食药 监机构改革: 整合与放权). China Newsweek.

Wang, Guannan. 2016. The adjustment of environment protection authorities at town level under the vertical management reform. China Environment News. December 21. Available online: http://epaper.cenews.com.cn/ html/2016-10/21/content_51384.htm (accessed on 5 September 2020). (In Chinese)

Wang, Xizi. 2018. Three principles that must be upheld when improving the State Organic Law (完善国家机构组 织法应完善三原则). Chinese Cadres Tribune. Available online: https://www.sohu.com/a/280263361_693202 (accessed on 14 October 2020). (In Chinese)

Wang, Xi, and Yang Deng. 2011. From 'unified supervision and management' to 'comprehensive coordination'-Analysis of Article 7 of the Environmental Protection Law of the People's Republic of China (从统一监督管理到综合协调). Jilin University Journal Social Sciences Edition. Available online: https://wenku.baidu.com/view/8e8672bba7c30c22590102020740be1e640ecc07.html (accessed on 15 October 2020). (In Chinese)

Wang, Puqu, and Bin Tang. 2019. An analysis of the party-government structure and functional mechanism of contemporary Chinese governance. (当代中国治理的党政结构与功能机制分析). Social Sciences in China. Available online: http://www.cssn.cn/zzx/201910/t20191017_5016180.shtml (accessed on 14 October 2020). (In Chinese)

Wen, Hong, and Huilong Li. 2019. Rethink of the Essence and Logic of Grassroots Formalism from the Perspective of Intergovernmental Relation (府际关系视角下基层形式主义的本质与逻辑重思). Exploration and Free Views 11: 102-10.

Wu, Shunze, and Changbo Qin. 2016. Implementation Path of China's Environmental Institutional Reform Towards a Vertical Structure below the Provincial Level (关于地方环保机构监察执法垂直管理制度改革重 点任务的基本考虑). Chinese Journal of Environmental Management. Available online: http://zghjgl.ijournal. cn/ch/reader/create_pdf.aspx?file_no=20160503\&flag=1\&journal_id=zghjgl\&year_id=2016 (accessed on 15 October 2020). (In Chinese)

Xi, Jinping. 2015. Explanation Concerning 'Recommendations of the CPC Central Committee for the 13th Five-Year Plan for Economic and Social Development'. People's Daily. November 4. Available online: http://theory.people.com.cn/n1/2015/1231/c83845-28001269.html (accessed on 17 July 2020). (In Chinese)

Xiong, Chao. 2019. Changes and challenges posed by the environmental vertical management of ecological environmental agencies' fulfillment of their responsibilities (环保垂改对生态环境部门职责履行的变革与挑 战). Academic Forum. [CrossRef]

Xu, Junzhong. 2020. Reflections on the political civilization and political style of the P.R. China on discussing the position of CPC (关于新中国政治文明与政治类型的思考一一兼谈中国共产党的政治定位). Open Times. Available online: http://www.aisixiang.com/data/122142-3.html (accessed on 5 November 2020). (In Chinese)

Yan, Houfu. 2015. Guarding ecological red lines is cadres' lifelong responsibility. People's Daily. August 4. Available online: http://opinion.people.com.cn/n/2015/0824/c1003-27504180.html (accessed on 7 September 2020). (In Chinese)

Yu, Jianxing, and Yindong Liu. 2020. The supervision system in vertical inter-governmental relationship: Taking central environmental protection supervision as a case (纵向政府间关系中的督察制度: 以中央环保督察为研 究对象). Academic Monthly 52: 69-80. 
Yuan, Fangcheng, and Yuwei Jiang. 2020. Is the promotion tournament still work? Eco-environment governance as a discussion area (晋升锦标赛依然有效? 以生态环境治理为讨论场域). Public Administration and Policy Review. Available online: http://blog.sina.com.cn/s/blog_d717c5900102ykr5.html (accessed on 14 October 2020). (In Chinese)

Zhang, Lu. 2019. Interview by Di Zhou. Semi-structured interview, Jingzhou. November 19.

Zhang, Pingdan. 2020. Creative Execution of Local Government in Modern Environmental Governance (构建现代 环境治理体系中地方政府的创造性执行). Governance Modernization Studies 36: 92-97.

Zhang, Lingyun, and Ye Qi. 2010. The difficulties of local environmental supervision (地方环境监管的困境解释). Chinese Public Administration.

Zhang, Weidong, Qingyuan Zhu, and Changhua Ju. 2017. Exploration in construction of environmental protection organization in township under the background of vertical management (垂直管理背景下乡镇环保机构建设 探索). Environmental Protection 7: 56-58.

Zhao, Huiyue. 2018. The History, Status Quo and Future of the 'Super-ministry reform' in the Field of Natural Resource and Environment Protection in China (资源与环境大部制改革的过去、现在与未来). China Environment Supervision 12. Available online: https://kns.cnki.net/kcms/detail/detail.aspx?FileName= HJJC201812009\&DbName=CJFQ2018 (accessed on 5 November 2020). (In Chinese)

Zhao, Xuguang, and Hongfeng Li. 2018. On the environmental vertical management reform from a perspective of rule of law (从法治视角探究生态环境监管体制改革). Studies on Socialism with Chinese Characteristics. Available online: https://m.sohu.com/a/252063039_729133 (accessed on 14 October 2020).

Zheng, Rong, Ming Jiang, and Yujie Jiang. 2013. On the reform of quality inspection institution (质检监管模式改 革与发展的探讨). Quality and Standardization 8. [CrossRef]

Zhou, Xueguang. 2008. Collusion among local governments: The institutional logic of a government behavior (基 层政府间的“共谋现象”- - 一个政府行为的制度逻辑). Sociological Studies. [CrossRef]

Zhou, Feizhou. 2009. The tournament system (锦标赛体制). Sociological Studies. Available online: https: //wenku.baidu.com/view/d58cd0bb9ec3d5bbfc0a7403.html (accessed on 14 October 2020). (In Chinese)

Zhou, Ke. 2016a. How can environmental agencies implement vertical management. People's Daily. September 26. Available online: http://opinion.people.com.cn/n1/2016/0120/c1003-28068435.html (accessed on 17 July 2020). (In Chinese)

Zhou, Ke. 2016b. Separating environmental management powers and local benefits: The far-reaching significance of environmental vertical management below the provincial level. People's Daily. January 20. Available online: http://env.people.com.cn/n1/2016/0120/c1010-28068473.html (accessed on 17 June 2020). (In Chinese)

Zhou, Wei. 2019. Legal predicament and the way out for the reform of China's environment supervision and law enforcement system (我国生态环境监管执法体制改革的法治困境与实践出路). Journal of Shenzhen University (Humanities \& Social Sciences) 36.

Zhou, Zhenchao. 2020. The historical changes on the relationship between the line management and block management (条块关系的变迁及影响机制——基于政府职责的视角). Academics 5: 24-31.

Zhou, Yanling, and Yingde Ji. 2020. Preliminary vertical management reform in Shandong Province creates a new pollution control system. China Environment News. February 19. Available online: https://www.cenews.com. cn/news/202002/t20200219_929103.html (accessed on 27 August 2020). (In Chinese)

Zhou, Zhao, and Xiangqin Liu. 2008. Administrative game play of local governments in rural industry environmental protection (乡镇工业环境保护中的地方政府行为博弯). Inquiry into Economic Issues. [CrossRef]

Zhou, Lian, Chong Liu, Xing Li, and Xi Weng. 2005. The phenomenon of adding the targets at every level and the incentives for the government officials (“层层加码”与官员激励). World Economic Papers.

Publisher's Note: MDPI stays neutral with regard to jurisdictional claims in published maps and institutional affiliations.

(C) 2020 by the author. Licensee MDPI, Basel, Switzerland. This article is an open access article distributed under the terms and conditions of the Creative Commons Attribution (CC BY) license (http://creativecommons.org/licenses/by/4.0/). 